\title{
Identification of the Causes of Students' Low Achievement in the Subject of English
}

\author{
Dr. Saqib Shahzad \\ Institute of Education \& Research \\ University of Science \& Technology, Bannu, (NWFP) Pakistan \\ Tel: 92-928-621-101Ｅ-mail: drsaqib577@yahoo.com \\ Dr. Riasat Ali \\ Institute of Education \& Research \\ University of Science \& Technology, Bannu, (NWFP) Pakistan \\ Tel: 92-928-621-101Ｅ-mail: drsriasatali@yahoo.com
}

Dr. Hukamdad

Lecturer, Department of education

NUML University Islamabad, Pakistan

E-mail: drhukamdad@gmail.com

Dr. Muhammad Zaigham Qadeer

Project Director CIEDA. Ministary of education Islamabad, Pakistan

E-mail: zaigham_70@yahoo.com

Habib Ullah

M.Phil Scholar, University of Science and Technology, Bannu, Pakistan

Tel: 92-928-621-101_E-mail: habib_6555@yahoo.com

\begin{abstract}
This study was aimed to find out the Causes of Students' low achievement in the subject of English at Secondary Level. The main objectives of the study were: To analyze the results of the students in the subject of English at Secondary level. To identify the role of curriculum in students' low achievement in the subject of English at Secondary level. To analyze the role of teachers in students low achievement in the subject of English at Secondary level. To identify the impact of environment on low achievement of students in the subject of English at Secondary level. The questionnaire was pilot tested before they were administered to sample. After collection, interpretation and analysis of data the researcher make recommendations for the stakeholders and general public. The study was delimited to 52 government high schools in North West Frontier Province of Pakistan. Questionnaire was the tool of data collection. The results show that Traditional oriented curriculum, incompetent English language teachers and harsh classrooms environment are the causes of student's low achievement in English. The researcher recommends that market oriented curriculum, competent English language teachers and conducive classrooms environment will improve the achievement level of the students in the subject of English.
\end{abstract}

Keywords: Low achievement, Stakeholders, Market oriented

\section{Introduction}

Progress and advancement of the countries of the world are always related to the kind of education they offer to their people. The more the people of societies are educated, the more they are civilized and well disciplined. It is 
through education that a person gets an insight to understand and solve his problems as well as those of his society. Secondary education is an important sub-sector of the entire education system. On the one hand, it provides middle level workers for the economy and on the other hand it acts as a feeder for the higher education. The quality of higher education depends upon the quality of secondary education. This level of education therefore, needs to be organized in such a way that it should prepare as well as make them able to adjust with their practical lives meaningfully and productively (Bhatti, 1987).

English is a vehicle of thought and lack of command over it is bound to make thoughts inexpressible. Only those who can understand any language can express themselves in that language. Globalization will increase the power of English, because it will open up more jobs for those who know it. These jobs will be controlled by multinational bureaucracy, United States, IMF and World Bank etc, which have started operation increasingly in English. This will increase demand for English schooling, which will make parents invest in English at the cost of their own languages. In the teaching of English, the teachers generally use translation method which is an old method of teaching, therefore, our students cannot get command over English language as evident from the fact that there are a large number of students who fail in English, because of lack of language learning environment, outdated curriculum, rigid teaching methods and incompetent English language teachers in the academic and professional areas. Functional grammar is not taught and practiced in the classrooms. More importance is given to the teaching of English Text-books. In order to study English as a second language and be successful at it, the students must be helped by the teachers to acquire four art skills in the language, namely; speaking, reading, listening and writing (Skutnabb, 2000).

Mueen (1992) says that English is used as an official language in Pakistan as 80 percent correspondence is carried out in English and it needs to be fostered as a means of education, communication and a practical tool. Pakistan and other non-English speaking countries throughout the world are realizing that if English language teaching is neglected, there will be decline in the field of science, technology and commerce. Keeping in view the importance of the English language in Pakistan, the achievement of the students in the subject of English is not up to the mark. Ammena (1983) has analyzed the situation in Pakistan and noticed that there is a rapid and marked decline not only in the students' knowledge of English literature and their response to it, but chiefly in the proper use of English syntax. Lack of knowledge mainly about the construction of sentences, the appropriate use of propositions and the correct use of verbs and tenses is the main deficiency of students. Majority of the students find them incapable of expressing their thoughts in English and that is why essay writing becomes the most difficult and challenging task for them.

This situation in Pakistan requires as changes in attitude and practices as far as teaching of English is concerned. There may be reasons for the marked decline, but the discussion with the experts in English and the senior teachers of English reveals that the main reason of it is that English grammar is not given due importance, its rules are taught in isolation and sufficient practice is not given in the use of different aspects of grammar in reading, writing, speaking and listening. Functional grammar is not taught and practiced in the classroom. This situation calls for a change in our teaching methods and the use of different techniques of teaching (Ali, 2002).

Haycraft (1993) says that, the Asian people are facing problem in teaching and learning of English while those problems include lack of experts knowledge, lack of spoken English, lack of reliable assessment, lack of effective audio-visual aids, harsh classroom environment, overcrowded classrooms, ineffective teaching methodology which are making English effective.

Mausoor (1993) analyzed that the students even after years of learning English as a compulsory subject, lacked fluency and faced difficulties in English language usage. A critical look at the English learning situation displayed out dated and in-efficient course and teaching methods. The teachers were not properly trained and there was hardly any interaction between students and the teachers. The spoken skill was completely ignored. It was not a part of the English examination.

In light of the above mentioned facts, the teaching learning process has been failed to produce quality, competency, creativity and excellence in the students. There is an intensive competition among the nations of the world for their survival as well as prosperity of their people. To improve the creative abilities of the students, curricula, teaching methods, evaluation systems are required to be changed.

\section{Method and procedure}

The major purpose of the study was to identify the causes of student's low achievement in the subject of English. All the male Head teachers and English teachers of Government Secondary Schools of North West Frontier Province were taken as population of the study. $52 \mathrm{Head}$ teachers and 208 English teachers were selected as sample of the study. The total sample size was two hundred and sixty. After studying the relevant literature a 
questionnaire was developed by the researcher. The developed questionnaire was validated through pilot testing. The researcher personally visited all the sampled institutions and respondents. The collected data was tabulated, analyzed and interpreted through means, percentage, standard deviation and ANOVA, in light of the objectives of the study.

\section{Data Analysis}

The data collected on five point scales was tabulated, analyzed and interpreted in the light of objectives of the study. The ANOVA and Z-test were applied to analyze and interpret the results at 0.05 level of significance, null hypotheses were used to accept or reject the hypotheses.

\section{Conclusions}

1. It is evident from the study that one of the main causes of students' low achievement in English is traditional content/knowledge oriented curriculum.

2. Maximum respondents were of the view that incompetent and professionally unskilled English language teachers were the cause of students' low achievement in English.

3. The study revealed that harsh classroom environment, which was often rowdy, congested and noisy is the cause of students' low achievement in English.

\section{Recommendations}

1 It was found in the study that curriculum plays a vital role in obtaining the objectives of Education .It is recommended that curriculum should be made activity based, market oriented and there should be horizontal and vertical articulation among different concepts.

2 As the study reveals that, most of the English teachers are not highly professionally skilled and qualified in English language. So it is recommended that well qualified and competent English language teachers should be appointed.

3 The result of the study showed that a congenial and conducive environment facilitate language teaching and learning. So it is recommended that Government should provide conducive environment by providing language lab A.V. aids related to language.

\section{References}

Ali, k. (2002). Problems of English language in Pakistan. Khyber Printing Press, Peshawar, Pakistan. Pp. 33.

Ammena, K. (1983). Teaching of English. Longman Hand books, USA. Pp. 41.

Bhatti, M.A. (1987). Secondary Education in Pakistan, Perspective Planning. National Education Council, Islamabad Pakistan., Pp. 49.

Government of Pakistan. (1992). National Education Policy. Ministry of Education Islamabad, Pakistan.

Haycraft, J. (1993). An introduction to English language Teaching. Oxford University Press, London. PP. 43.

Mansoor, S. (1993). Punjabi, Urdu, English in Pakistan. A Sociolinguistic study, Lahore, Pakistan. Pp. 53.

Mueen, A. (1992). English Language Teaching in Pakistan. National Book Foundation, Islamabad, Pakistan. Pp. 56.

Skutnabb, (2000). English Language and future trends. Oxford University Press, London, UK. Pp. 54.

Table 1. Showing average frequency of students' failure in the subject of English for five years i.e. 2004 - 2008

\begin{tabular}{|l|c|c|c|}
\hline \multicolumn{1}{|c|}{ Boards } & Total No. of Students & No. of Students failed & No. of failed \% age \\
\hline Bannu & 40056 & 20617 & $51.47 \%$ \\
\hline Kohat & 51673 & 28438 & $55.00 \%$ \\
\hline Peshawar & 49539 & 28613 & $57.76 \%$ \\
\hline Swat & 29114 & 15765 & 54.15 \\
\hline Mardan & 36769 & 14716 & $40.02 \%$ \\
\hline
\end{tabular}

On analysis of SSC results of last five years of various Educational boards, it was revealed that most of the students failed in English. 
Table 2. Showing responses of teachers regarding curriculum

\begin{tabular}{|l|c|c|c|c|}
\hline \multicolumn{1}{|c|}{ Source of variations } & $\begin{array}{c}\text { Degree of } \\
\text { freedom }\end{array}$ & Sum Squares & Means Squares & F \\
\hline Between sums of squares & 4 & 381693.54 & 95423.38 & 28.03 \\
\hline Within sum of squares & 25 & 85100.33 & 3404.01 & \\
\hline Total & 29 & 466793.87 & & \\
\hline
\end{tabular}

Table no. 2 shows that the value of F (calculated) 28.03 is greater than the value of $F$ (tabulated) 2.76 and the result is significant at 0.05 level, therefore hypothesis is rejected. It is evident from this study that traditional curriculum is one of the major causes of students low achievement in English.

Table 3. Showing responses of teachers regarding assessment system

\begin{tabular}{|l|c|c|c|c|}
\hline \multicolumn{1}{|c|}{ Source of variation } & Degree of freedom & Sums squares & Means squares & F \\
\hline Between sums of squares & 4 & 554217 & 138554.25 & 51.36 \\
\hline Within sums of squares & 20 & 53590 & 2697.50 & \\
\hline Total & 24 & 607807 & & \\
\hline
\end{tabular}

The table no 3 depicts that the value of F (calculated) 51.36 is greater than the value of $F$ (tabulated) 2.87 and the result is significant at 0.05 level, therefore hypothesis is rejected. It is analyzed that majority of the respondents believe that there are drawbacks in our educational assessment system and it is one of the causes of students' law achievement in English.

Table 4. Showing responses of teachers regarding competency of English teachers

\begin{tabular}{|l|c|c|c|c|}
\hline \multicolumn{1}{|c|}{ Source of variations } & Degree of freedom & Sums squares & Means squares & F \\
\hline Between sums of squares & 4 & 138798.6 & 34699.60 & 15.50 \\
\hline Within sums of squares & 15 & 44666.00 & 2233.30 & \\
\hline Total & 19 & 183464.40 & & \\
\hline
\end{tabular}

The table no. 4 shows that the value of F (calculated) 15.50 is greater than the value of F (tabulated) 2.87 and the result is significant at 0.05 level, therefore hypothesis is rejected. It is inferred from the above table that majority of the English teachers have no competency in English language skills.

Table 5. Showing responses of teachers regarding classroom environment

\begin{tabular}{|l|c|c|c|c|}
\hline \multicolumn{1}{|c|}{ Source of variations } & Degree of freedom & Sums squares & Means squares & F \\
\hline Between sums of squares & 4 & 230459.14 & 57614.80 & 11.90 \\
\hline Within sums of squares & 30 & 144755.86 & 4825.20 & \\
\hline Total & 34 & 375215.00 & & \\
\hline
\end{tabular}

The above table no.5 explains that the value of F (calculated) 11.90 is greater than the value of F (tabulated) 2.69 and the result is significant at 0.05 level, the hypothesis is rejected. It is analyzed that majority of the respondents are of the view that classroom environment is not conducive and it is one of the causes of students' low achievement in English. 